\title{
A SZOCIOÖKONÓMIAI HÁTTÉRVÁLTOZÓK SZEREPE A NETFIT MÉRÉSBEN
}

Szerzők:

Nagy Zsuzsa

Debreceni Egyetem (Magyarország)

Laoues-Czimbalmos Nóra

Debreceni Egyetem (Magyarország)

Müller Anetta

Debreceni Egyetem (Magyarország)

Első szerző e-mail címe:

nagizsuzsa@gmail.com

\section{Lektorok:}

\author{
Bíró Melinda \\ Debreceni Egyetem (Magyarország). \\ Lenténé Puskás Andrea \\ Debreceni Egyetem (Magyarország)
}

Nagy Zsuzsa, Laoues-Czimbalmos Nóra, Müller Anetta (2018): A szocioökonómiai háttérváltozók szerepe a NETFIT mérésben. Különleges Bánásmód, IV. évf. 2018/4. szám, 33-44. DOI 10.18458/KB.2018.4.33

\begin{abstract}
Absztrakt
A testalkati mutatók és a motoros képességek felmérése a magyar Nemzeti Egységes Tanulói Fittség Tesztet (továbbiakban: NETFIT) a köznevelésbe kötelezöen 2013/14-es tanévtöl vezették be, melynek célja, hogy a mindennapos testnevelés hatásait tudja kimutatni, a tanulók fittségi és testalkati paramétereiben. A tesztek országos eredményeinek bemutatásánál az is kiderül, hogy a fittségi állapotot meghatározzák a genetikai adottságok, a családi háttér és a környezet is (Csányi et. al., 2015, Csányi és Kaj 2017), így az eredményeket ezen tényezök közös kontextusában lehet értelmezni. Kutatásunkban célunk volt megvizsgálni a budapesti középiskolás fiú tanulók NETFIT adatait a családi háttérvizsgálatokkal kiegészitve. Kutatásunk során arra kerestük a választ, hogy hogyan alakul a Budapesti Müszaki Szakképzési Centrumban tanuló fiúk fittségi profilja a NETFIT próbákban mutatott eredmények alapján. Milyen összefüggés van a családi háttér és a NETFIT mérésen nyújtott teljesitmény között?

Felmérésünket a Budapesti Müszaki Szakképzési Centrum egyik legnagyobb iskolájában végeztük a Budapesti Müszaki Szakképzési Centrum Újpesti Két Tanitási Nyelvü Müszaki Szakgimnáziuma és Szakközépiskolájában. Összesen 342 fö fiú tanulót vontunk be a vizsgálatba, ahol egy 35 kérdésböl álló kérdöiv segítségével kisérletet tettünk a NETFIT eredmények és a szocioökonómiai háttérmutatók összefüggéseinek feltárására.

Számos kutatás igazolja, hogy a kedvezöbb SES-sel rendelkezö tanulói csoportok, általában kedvezőbb fittségi mutatókkal rendelkeznek (Jiménez-Pavon és tsai, 2010, Ortega és tsai, 2013, Vandendriessche és tsai., 2012). Arra is számos bizonyiték áll rendelkezésre, hogy az országon belül kimutatható regionális szintü fittségiállapot-mutatók magasabbak a kedvezöbb SES-sel rendelkezö régiókban (Charlton és tsai, 2014, Golle és tsai, 2014, Cleland és tsai, 2009, Welk, Saint-Maurice és Csányi, 2015). Kutatásunk során megállapitottuk, hogy a fejlesztésre szoruló tanulók leginkább a kisközségekböl kerülnek ki, mintegy 58,3\%-uk szorul fejlesztésre. Ezek az értékek szignifikánsan eltérnek (khi=218,6, df=20, p=0,000). Az életmód
\end{abstract}


kialakitásának alappillére a család (Mezö 2018), amelynek szokásai, alakitják a gyermek sporthoz való viszonyát, s később igen nehéz azokat megváltoztatni (Herpainé et. al, 2017, Herpainé 2018). A vizsgálat bizonyitotta, hogy az adott mintán a vizsgált fiú tanulóknál az apa sportolási szokása döntöen meghatározó, azonban az anya sportolási szokása nincs akkora hatással a vizsgált személyek sportolási szokására. Javaslatot teszünk a NETFIT teszt battériájának kiterjesztésére a vizsgált személy szocioökonómiai háttérvizsgálatával.

Kulcsszavak: NETFIT, tesztbattéria, sport, testnevelés, szocioökonómiai háttér, életmód

Diszciplina: pedagógia, sporttudomány

\section{Abstract}

Assessment of physical indicators and motor skills is the Hungarian National Unified Student Fitness Test (hereinafter referred to as "NETFIT"), which was introduced in public education from the 2013/14 academic year, which aims to demonstrate the effects of everyday physical education on the fitness and physiological parameters of students. When showing the national results of the tests, it is also shown that the fitness condition is determined by the genetic conditions, the family background and the environment (Csányi et al., 2015, Csányi and Kaj 2017) so results can be interpreted in a common context of these factors. In our research, we aimed at examining NETFIT data from Budapest secondary school students, supplemented by family background surveys. During our research, we sought to find out how the fitness profile of boys studying at the Budapest Technical Vocational Training Center is based on the results of the NETFIT tests. What is the relationship between family background and NETFIT performance?

Our survey was carried out at one of the largest schools of the Budapest Technical Vocational Training Center at the Technical Training Center in Ujpesti Two Teaching Grammar School and Technical College of the Budapest Technical Vocational Training Center. A total of 342 pupils were included in the study, where a questionnaire of 35 questions was used to investigate the correlations of NETFIT results and socioeconomic background indicators.

Numerous studies have shown that the more favorable SES students have generally more favorable fitness indicators (Jiménez-Pavon et al., 2010, Ortega et al., 2013, Vandendriessche et al., 2012). There is also a great deal of evidence that country-specific regional status indicators are higher in regions with more favorable SES (Charlton et al., 2014, Golle et al., 2014, Cleland et al., 2009, Welk, Saint-Maurice and Csányi, 2015). During our research, we found that students in need of development mostly come from small communities, with some 58.3\% developing. These values differ significantly ( $k h i=218.6, d f=$ $20, p=0.000$ ). The basic pillow of the lifestyle is the family (Field 2018), the habits of which shape the child's relationship with sports, and later it is very difficult to change them (Herpain et al., 2017, Herpainé 2018). The study showed that the father's sporting habits are decisive in the case of the examined boy's pupils, but the mother's sporting habit does not have the same effect on the sportsman's behavior. We propose to extend the NETFIT test bundle with the socioeconomic background examination of the examined person.

Keywords: NETFIT, test betting, sport, physical education, socioeconomic background, lifestyle

Disciplines: pedagogy, sport science 
Az elhízás, túlsúly népegészségügyi jelentősége mára eléri a dohányzásét, hatalmas terheket róva ezzel az egészségügyi rendszerre (Iski és Rurik, 2014). A WHO a kövérséget a világ tíz legjelentősebb egészségügyi problémái közé sorolta (WHO, 2016). Magyarországon is, mint a világ több országában, a gyerekkori elhízás pervalenciája növekszik (Martos, 2010), illetve a középiskolás korosztályt is érinti (Müller, 2018).

Ezeket az adatokat és tendenciákat tekintve a mindennapos testnevelés bevezetésének szükségessége és létjogosultsága mára megkérdőjelezhetetlenné vált. A folyamatos tantervi változások és NAT viták után bevezetésre került a mindennapos testnevelés (Hamar, 2012, 2013).

A 2012/2013-as tanévtől az 1., az 5. és a 9. évfolyamon, majd felmenő rendszerben minden évfolyamon bevezetésre került a mindennapos testnevelés kötelező jelleggel, melyben a testilelki egészségre nevelés gondolata is megfogalmazódott (NAT, 2012).

A mindennapos testneveléssel kapcsolatban, még csak kezdeti tapasztalatokról számolnak be a kutatások (Fintor, 2016; Müller, 2017; Meszlényi et. al., 2017; Szépné és Balatoni, 2017, Szépné et. al., 2017; Juhász et. al., 2016; 2017; Müller et. al., 2018).

Hazánkban a mindennapos testnevelés bevezetésével, egy kedvező oktatáspolitikai helyzetbe kapcsolódott be a Nemzeti Egységes Tanulói Fittségi Teszt (NETFIT). Ez a fittségi teszt kilenc mérést foglal magába, melynek eredményei alapján négy profilban értékeli a tanulók állapotát: mutatja az állóképességet, a vázizomzat fittségét, a hajlékonyságot, illetve a testösszetételt, tápláltsági státuszt. Az eredmények alapján a tanulókat be tudjuk sorolni az alábbiak szerint: egészségzóna, a fejlesztésre szorulók, a fokozott fejlesztést igénylök csoportja (Csányi et. al., 2015; Csányi és Kaj, 2017). A kutatók előtt a sporthoz való viszony és a társadalmi réteghovatartozás összefonódása, valamint a sporttevékenységek státusszimbólum-értéke is ismeretes (Bocsi, 2014).

A megfelelő fizikai aktivitás és a kedvező fittségi állapot pozitívan korrelál az egyes egészségindikátorokkal, és prevenciót jelent számos betegséggel szemben (Apor, 2009; 2011; Lee, 2010; Youssef, 2014; Pluhár et. al., 2004; Helmrich et. al., 1991; Stampfer et. al., 2000; Friedenrich, 2001; Walsh et. al., 2011; Ross et. al., 2000), valamint a stresszkezelés egy hatékony módszere (Bodolai et. al., 2016).

Célkitüzés

Kutatásunkban célunk volt megvizsgálni a budapesti középiskolás fiú tanulók NETFIT adatait a családi háttérvizsgálatokkal kiegészítve. Kutatásunk során arra kerestük a választ, hogy hogyan alakul a Budapesti Müszaki Szakképzési Centrumban tanuló fiúk fittségi profilja a NETFIT próbákban mutatott eredmények alapján. Milyen összefüggés van a családi háttér és a NETFIT mérésen nyújtott teljesítmény között?

Feltételezhetően a családi háttér jellemzői eltérően hatnak a tanulók teljesítményére, a sport iránti igény kialakulására. A szocioökonómiai mutatók és a családi környezet befolyásolják a középiskolások fittségi eredményeit.

\section{Módszer}

Felmérésünket a Budapesti Müszaki Szakképzési Centrum egyik legnagyobb iskolájában végeztük a Budapesti Műszaki Szakképzési Centrum Újpesti Két Tanítási Nyelvű Müszaki Szakgimnáziuma és Szakközépiskolájában. Összesen 342 fö fiú tanulót vontunk be a vizsgálatba, ahol egy 35 kérdésből álló kérdőív segítségével kísérletet tettünk a NETFIT eredmények és a szocioökonómiai háttérmutatók összefüggéseinek feltárására. 
Megvizsgáltuk a lakóhely és a NETFIT eredmények korrelációját, a neveltetésük során a szülői támogatást a sport szeretetének elmélyüléséhez, a dohányzást, valamint a mindennapi testnevelés bevezetésének hatását, tanulói szemszögből.

A kutatás ezen része, az ehhez tartozó kutatás iskolai csoportjaira korlátozódott.

Az online kérdőívek kitöltése önkéntes volt. A kitöltés előtt ismertettük a vizsgálat célját és a kitöltés módját. Az adatfelvételbe bevont célcsoportok a tavalyi évben felmért (NETFIT) tanulók voltak.

Az adatokat SPSS statisztikai próba segítségével dolgoztuk fel. Számítottunk alapstatisztikai mutatókat (átlag, szórás), az összefüggések vizsgálatára khi-négyzet próbát használtunk.

\section{Minta}

A felmért tanulók (kivéve a kimenő osztályok és a bejövő osztályok $n=342$ ) szocioökonómiai hátterét tárjuk fel.

A megkérdezett tanulók korosztályos eloszlása a következöképpen nézett ki, 20 éves tanulók a minta 2\%-át, 19 évesek a 1\%-át, a 18 évesek az 5\%-át tették ki, míg a 17 és 16 évesek a 55\% -ot illetve a 37\%-át fedték le.

A tanulók 51,9\%-a volt a felmérés szerint az „egészség zónában”, 16,6\%-a a „fejlesztés szükséges” zónában és csupán $0,9 \%$-a a „fokozott fejlesztés szükséges zónában”.

\section{Eredmények}

A vizsgálat során elöször az állandó lakhely és a NETFIT mérés eredményeinek kapcsolatát tártuk fel az adott mintán. Itt azt az eredményt kaptuk, hogy a lakóhely és a NETFIT zónákban történő végrehajtás erősen szignifikáns (lásd: 1. táblázat).

1. táblázat: Az állandó lakhely és a NETFIT zónák kapcsolata (Forrás: Szerzök)

\begin{tabular}{|l|r|r|r|r|r|}
\hline \multirow{2}{*}{$\begin{array}{c}\text { Azz elmúlt évben } \\
\text { melyik zónában } \\
\text { voltál átlagosan? }\end{array}$} & \multicolumn{5}{|c|}{ Fol van az állandó bejelentett lakhelyed? } \\
\cline { 2 - 6 } & Fóváros & Kisközség & $\begin{array}{l}\text { Megyei jogú } \\
\text { város }\end{array}$ & \multicolumn{1}{|c|}{ Város } \\
\hline Egészség zóna & $76,1 \%$ & $45,5 \%$ & $25,0 \%$ & $33,3 \%$ & $51,3 \%$ \\
\hline Fejlesztés szükséges & $11,3 \%$ & $16,8 \%$ & $58,3 \%$ & $0,0 \%$ & $16,8 \%$ \\
\hline $\begin{array}{l}\text { Fokozott fejlesztés } \\
\text { szükséges }\end{array}$ & $0,0 \%$ & $0,0 \%$ & $0,0 \%$ & $0,0 \%$ & $2,7 \%$ \\
\hline Nem tudom & $12,7 \%$ & $37,8 \%$ & $0,0 \%$ & $66,7 \%$ & $23,9 \%$ \\
\hline
\end{tabular}

* khi-négyzet $=218,619, d f=20, p=0,000$

Látható, hogy az egészségzónában a falun élők 76,1\%-a, a városban élők 51,3\%-a, a fövárosban 45,5\%-a van, legrosszabb az eredmény a megyei jogú városokban 33,3\%--kal és a kisközségben élők esetében 25\%-kal. A fejlesztésre szoruló tanulók leginkább a kisközségekből kerülnek ki 58,3\%-uk fejlesztésre szorul, ezek az értékek szignifikánsan eltérnek $(\mathrm{khi}=218,6, \mathrm{df}=20, \mathrm{p}=0,000)$. A család, mint elsődleges nevelési színtér és az informális tanulás egyik legfontosabb helyszíne, eröteljesen befolyásolja a gyermek egészségtudatos magatartásának kialakulását, és ezen belül a testkultúrához, testedzéshez való hozzáállását is. (lásd: 2 . táblázat).

Megvizsgáltuk az édesanya és az édesapa sportolási szokásait és összevetettük a tanuló sportolási szokásaival, ahol is erős szignifikanciát tapasztaltunk $(\mathrm{khi}=152,2, \mathrm{df}=16$, $\mathrm{p}=0,00)$. 
2. táblázat: A szülők sportolási szokásának viszonyitása a tanuló sportolási szokásához (Forrás: Szerzök)

\begin{tabular}{|l|r|r|r|r|}
\hline \multirow{2}{*}{$\begin{array}{c}\text { Jelenleg sportolnak-e a szüleid? } \\
\text { Anya/Nevelöanya }\end{array}$} & \multicolumn{4}{|c|}{ Alkalmanként mennyi időt töltesz sportolással? } \\
\cline { 2 - 5 } & 1 óránál kevesebbet & $1-2$ órát & $3-4$ órát & 4 óránál többet \\
\hline Havonta vagy ritkábban & $30,0 \%$ & $20,0 \%$ & $0,0 \%$ & $0,0 \%$ \\
\hline Hetente, kéthetente & $15,2 \%$ & $76,1 \%$ & $3,3 \%$ & $5,4 \%$ \\
\hline Nem & $6,9 \%$ & $64,6 \%$ & $12,7 \%$ & $0,5 \%$ \\
\hline $\begin{array}{l}\text { Rendszeresen, hetente legalább 3-szor } \\
\text { sportol }\end{array}$ & $70,4 \%$ & $11,1 \%$ & $14,8 \%$ & $3,7 \%$ \\
\hline $\begin{array}{l}\text { Jelenleg sportolnak-e a szüleid? } \\
\text { Apa/Nevelöapa }\end{array}$ & 1 óránál kevesebbet & $1-2$ órát & $3-4$ órát & 4 óránál többet \\
\hline $\begin{array}{l}\text { Havonta vagy ritkábban } \\
\text { Hetente, kéthetente }\end{array}$ & $0,0 \%$ & $61,1 \%$ & $22,2 \%$ & $0,0 \%$ \\
\hline Nem & $27,8 \%$ & $50,0 \%$ & $16,7 \%$ & $1,4 \%$ \\
\hline $\begin{array}{l}\text { Rendszeresen, hetente legalább 3-szor } \\
\text { sportol }\end{array}$ & $14,7 \%$ & $61,3 \%$ & $9,2 \%$ & $0,5 \%$ \\
\hline
\end{tabular}

Az életmód, és ezen belül az egészséges életmód kialakításának alapvető befolyásoló színtere a család, melynek szokásai, rendje beleivódik a személyiségbe, s később igen nehéz azokat megváltoztatni, befolyásolni (Herpainé et. al., 2017). Amennyiben a család tagjai - föleg az édesapa és az édesanya - nem ismerik a helyes életvezetés, életmód és a testkultúra alapjait és szabályait, akkor nem várható el a gyermeküktől sem ugyanez (Keery et al., 2006; International Food Information Council (IFIC) Foundation, 2007).

A vizsgálat során szembetünő, hogy a vizsgált fiú tanulóknál az apa sportolási szokása döntően meghatározó, ahol az apa rendszeresen sportol ott nem volt olyan tanuló, aki legalább alkalmanként egy óránál kevesebb időt töltene mozgással, és kiugróan magas 77\% volt az 1-2 órát sportolással foglalkozók száma.

Az anya sportolási szokása nincs akkora hatással a vizsgált személyek sportolási szokására, hiszen hiába sportol, rendszeresen heti 3 alkalommal nem befolyásolja a gyermeke sportolási szokásait, hiszen az 1 óránál kevesebb sportolás nem számít sportolásnak.

A 2016-os Magyar Ifjúság Kutatás (Bauer et al., 2016) eredményei szerint minden tízedik válaszadó számára a szülei javasolták a mozgást, ami a Herpainé et. al. (2017) által vizsgált fiatalabb mintával összevetve hasonló eredményként volt értékelhető.

Ebből következett, hogy a sportolási szokások mutatóit is megvizsgáltuk az állandó lakóhely függvényben (lásd. 3. táblázat).

A könnyített testnevelés és az állandó lakóhely kérdéseknél az eltérés csak tendenciában figyelhető meg statisztikailag nem igazolható, azonban az összes többi ehhez tartozó variánssal szignifikáns az állandó lakhely.

Az egyéb sportfoglalkozások (sportkör, egyesületi sport...) látogatása a fóvárosban élökre jellemző, a leggyakrabban $41,4 \%$ ez következhet az infrastrukturális adottságokból és a lehetőségek szélesebb tárházából. Ezután a városban lakó tanulókat, mintegy 28,7\%-ukat jellemzi, valószínüsíthető hasonló okok miatt.

Azonban kiugróan magas a többi opcióhoz képest a „testnevelés órákon kívül is rendszeresen, legalább hetente 3 alkalommal sportolok kedvtelésként, nem versenyszerüen" lehetöségre adott válaszok közül, a faluban élök száma, ez abból következhet, hogy a településen sportegyesület nem müködik. 
KÜLÖNLEGES BÁNÁSMÓD, IV. ÉVF. 2018/4.

3. táblázat: Az állandó lakóhely és a sportolási szokások összevetése (Forrás: Szerzők)

\begin{tabular}{|c|c|c|c|c|c|c|c|}
\hline Sport & Válasz & Falu & Főváros & Kisközség & $\begin{array}{l}\text { Megyei } \\
\text { jogú város }\end{array}$ & Város & $\mathrm{p}$ \\
\hline \multirow[t]{2}{*}{ gyógytestnevelés } & $\begin{array}{l}\text { legkevésbé jellemző } \\
\text { rám }\end{array}$ & $22,80 \%$ & $38,30 \%$ & $3,90 \%$ & $1,00 \%$ & $34,10 \%$ & \multirow{2}{*}{0,00} \\
\hline & kevésbé jellemző rám & $0,00 \%$ & $77,40 \%$ & $0,00 \%$ & $0,00 \%$ & $22,60 \%$ & \\
\hline \multirow[t]{4}{*}{$\begin{array}{l}\text { könnyített } \\
\text { testnevelés }\end{array}$} & $\begin{array}{l}\text { legkevésbé jellemző } \\
\text { rám }\end{array}$ & $22,70 \%$ & $41,20 \%$ & $3,90 \%$ & $1,00 \%$ & $31,20 \%$ & \multirow{4}{*}{0,11} \\
\hline & kevésbé jellemző rám & $6,70 \%$ & $13,30 \%$ & $0,00 \%$ & $0,00 \%$ & $80,00 \%$ & \\
\hline & jellemző rám & $0,00 \%$ & $76,90 \%$ & $0,00 \%$ & $0,00 \%$ & $23,10 \%$ & \\
\hline & $\begin{array}{l}\text { leginkább jellemző } \\
\text { rám }\end{array}$ & $0,00 \%$ & $66,70 \%$ & $0,00 \%$ & $0,00 \%$ & $33,30 \%$ & \\
\hline \multirow{4}{*}{$\begin{array}{l}\text { Csak a } \\
\text { testnevelés órán } \\
\text { sportolok }\end{array}$} & $\begin{array}{l}\text { legkevésbé jellemző } \\
\text { rám }\end{array}$ & $17,90 \%$ & $41,00 \%$ & $5,10 \%$ & $1,50 \%$ & $34,40 \%$ & \multirow{4}{*}{0,14} \\
\hline & kevésbé jellemző rám & $27,90 \%$ & $32,60 \%$ & $4,70 \%$ & $0,00 \%$ & $34,90 \%$ & \\
\hline & jellemző rám & $17,80 \%$ & $53,40 \%$ & $0,00 \%$ & $0,00 \%$ & $28,80 \%$ & \\
\hline & $\begin{array}{l}\text { leginkább jellemzô } \\
\text { rám }\end{array}$ & $35,50 \%$ & $32,30 \%$ & $0,00 \%$ & $0,00 \%$ & $32,30 \%$ & \\
\hline \multirow{8}{*}{$\begin{array}{l}\text { A testnevelés } \\
\text { órák mellett is } \\
\text { sportolok } \\
\text { versenyszerűen }\end{array}$} & $\begin{array}{l}\text { legkevésbé jellemző } \\
\text { rám }\end{array}$ & $26,60 \%$ & $39,10 \%$ & $0,00 \%$ & $0,00 \%$ & $34,30 \%$ & \multirow{4}{*}{0,01} \\
\hline & kevésbé jellemző rám & $22,20 \%$ & $33,30 \%$ & $7,40 \%$ & $3,70 \%$ & $33,30 \%$ & \\
\hline & jellemző rám & $6,80 \%$ & $54,20 \%$ & $3,40 \%$ & $0,00 \%$ & $35,60 \%$ & \\
\hline & $\begin{array}{l}\text { leginkább jellemző } \\
\text { rám }\end{array}$ & $18,40 \%$ & $41,40 \%$ & $9,20 \%$ & $2,30 \%$ & $28,70 \%$ & \\
\hline & $\begin{array}{l}\text { legkevésbé jellemző } \\
\text { rám }\end{array}$ & $1,60 \%$ & $26,60 \%$ & $0,00 \%$ & $0,00 \%$ & $71,90 \%$ & \multirow{4}{*}{0,00} \\
\hline & kevésbé jellemző rám & $45,00 \%$ & $35,00 \%$ & $0,00 \%$ & $1,70 \%$ & $18,30 \%$ & \\
\hline & jellemző rám & $22,50 \%$ & $40,00 \%$ & $5,00 \%$ & $0,00 \%$ & $32,50 \%$ & \\
\hline & $\begin{array}{l}\text { leginkább jellemző } \\
\text { rám }\end{array}$ & $19,10 \%$ & $50,00 \%$ & $5,60 \%$ & $1,10 \%$ & $24,20 \%$ & \\
\hline \multirow{4}{*}{$\begin{array}{l}\text { A testnevelés } \\
\text { órákon kívül is } \\
\text { rendszeresen, } \\
\text { legalább hetente } \\
3 \text { alkalommal } \\
\text { sportolok } \\
\text { kedvtelésként, } \\
\text { nem } \\
\text { versenyszerüen }\end{array}$} & $\begin{array}{l}\text { legkevésbé jellemző } \\
\text { rám }\end{array}$ & $17,80 \%$ & $32,70 \%$ & $0,00 \%$ & $0,00 \%$ & $49,50 \%$ & \multirow{4}{*}{0,00} \\
\hline & kevésbé jellemző rám & $16,80 \%$ & $49,50 \%$ & $1,00 \%$ & $3,00 \%$ & $29,70 \%$ & \\
\hline & jellemző rám & $15,20 \%$ & $63,00 \%$ & $4,30 \%$ & $0,00 \%$ & $17,40 \%$ & \\
\hline & $\begin{array}{l}\text { leginkább jellemző } \\
\text { rám }\end{array}$ & $30,90 \%$ & $33,00 \%$ & $9,60 \%$ & $0,00 \%$ & $26,60 \%$ & \\
\hline
\end{tabular}

Nemzetközi és hazánkban végzett longitudinális vizsgálatok megállapították, hogy az eltérő szocioökonómiai hátterü családokban felnövő gyermekek növekedési mintázata, tápláltsági státusza között eltérés figyelhető meg. A kedvezőtlen szocioökonómiai hátterü családok gyermekei a növekedésben lemaradtak és körükben az elhízás és az alultápláltság jelensége gyakoribb (Bodzsár és Zsákai, 2012; Bodzsár et al., 2015a; Bodzsár et al., 2015b; D'Orsi et al., 2014; Fors et al., 2009; Pikhartova et al., 2014).

Ez alapján megvizsgáltuk a szülők iskolai végzettsége és a NETFIT-ben elért egészségügyi zónákat (lásd: 4. táblázat). 
4. táblázat Szülök iskolai végzettsége NETFIT besorolás összehasonlitása (Forrás: Szerzök)

\begin{tabular}{|c|c|c|c|c|}
\hline & \multicolumn{4}{|c|}{ Az elmúlt évben melyik zónában voltál átlagosan? } \\
\hline $\begin{array}{l}\text { Mi édesanyád/nevelöanyád } \\
\text { legmagasabb iskolai végzettsége? }\end{array}$ & Egészség zóna & $\begin{array}{l}\text { Fejlesztés } \\
\text { szükséges }\end{array}$ & $\begin{array}{l}\text { Fokozott } \\
\text { fejlesztés } \\
\text { szükséges }\end{array}$ & Nem tudom \\
\hline Befejezett 8-9. osztály & $38,9 \%$ & $5,6 \%$ & $0,0 \%$ & $55,6 \%$ \\
\hline Egyetemi diploma & $38,5 \%$ & $26,9 \%$ & $3,8 \%$ & $23,1 \%$ \\
\hline Főiskolai diploma & $64,9 \%$ & $32,5 \%$ & $0,0 \%$ & $2,6 \%$ \\
\hline $\begin{array}{l}\text { Szakközépiskolai érettségi } \\
\text { gimnázium vagy líceum érettségivel }\end{array}$ & $45,1 \%$ & $12,7 \%$ & $1,2 \%$ & $38,2 \%$ \\
\hline Szakmunkásképzö/Szakiskola & $55,6 \%$ & $8,3 \%$ & $0,0 \%$ & $16,7 \%$ \\
\hline Technikum & $88,7 \%$ & $6,7 \%$ & $0,0 \%$ & $6,7 \%$ \\
\hline $\begin{array}{c}\text { Mi édesapád/nevelőapád } \\
\text { legmagasabb iskolai végzettsége? }\end{array}$ & Egészség zóna & $\begin{array}{l}\text { Fejlesztés } \\
\text { szükséges }\end{array}$ & $\begin{array}{l}\text { Fokozott } \\
\text { fejlesztés } \\
\text { szükséges }\end{array}$ & Nem tudom \\
\hline Egyetemi diploma & $70,6 \%$ & $20,6 \%$ & $2,9 \%$ & $0,0 \%$ \\
\hline Főiskolai diploma & $51,8 \%$ & $10,7 \%$ & $0,0 \%$ & $37,5 \%$ \\
\hline $\begin{array}{l}\text { Szakközépiskolai érettségi } \\
\text { gimnázium vagy líceum érettségivel }\end{array}$ & $61,6 \%$ & $7,1 \%$ & $2,0 \%$ & $29,3 \%$ \\
\hline Szakmunkásképzö/Szakiskola & $41,0 \%$ & $29,0 \%$ & $0,0 \%$ & $28,0 \%$ \\
\hline Technikum & $45,7 \%$ & $19,6 \%$ & $0,0 \%$ & $26,1 \%$ \\
\hline
\end{tabular}

Megállapíthatjuk, hogy magasabb iskolai végzettségü (egyetem, főiskola) szülők gyermekei legnagyobb arányban az egészségzónában müködnek $\mathrm{Az}$ édesanya egyetemi végzettsége esetén 38,5\%-a, föiskolai végzetsége esetén 64,9\%-a végzett ebben a zónában. A Szignifikancia szint mind az anya $(\mathrm{khi}=234,1, \mathrm{df}=28, \mathrm{p}=0,00)$, mind az apa esetében (khi=137,9 $\mathrm{df}=28, \mathrm{p}=0,00)$ erös.

Míg az édesapa egyetemi végzettsége esetén 70,6\%, föiskolai végzettsége esetén $51,8 \%$-a tartozik az egészségzónába. Ennek oka magyarázható, a szülők sporthoz füződő viszonyával (lásd: 5. táblázat).

5. táblázat: A szülők viszonyulása a sporthoz és a NETFIT mérési eredmények összevetése (Forrás: Szerzök)

\begin{tabular}{|l|c|c|c|c|c|}
\hline \multirow{2}{*}{$\begin{array}{c}\text { Neveltetésed során mennyire tartották } \\
\text { fontosnak szüleid, hogy átadják a sport } \begin{array}{c}\text { Azeretetét? } \\
$\cline { 2 - 6 }\end{array}\end{array}} & $\begin{array}{c}\text { Nem } \\
\text { válaszolt }\end{array}$ & $\begin{array}{c}\text { Egészség } \\
\text { zóna }\end{array}$ & $\begin{array}{c}\text { Fejlesztés } \\
\text { szükséges }\end{array}$ & $\begin{array}{c}\text { Fokozott } \\
\text { fejlesztés } \\
\text { szükséges }\end{array}$ & $\begin{array}{c}\text { Nem } \\
\text { tudom }\end{array}$ \\
\hline Egyáltalán nem tartották fontosnak & $0,0 \%$ & $0,0 \%$ & $87,5 \%$ & $0,0 \%$ & $12,5 \%$ \\
\hline Fontosnak tartották & $2,4 \%$ & $51,6 \%$ & $15,0 \%$ & $0,4 \%$ & $30,5 \%$ \\
\hline Nem tartották fontosnak & $5,4 \%$ & $56,8 \%$ & $24,3 \%$ & $5,4 \%$ & $8,1 \%$ \\
\hline Rendkívül fontosnak tartották & $0,0 \%$ & $64,7 \%$ & $9,8 \%$ & $0,0 \%$ & $25,5 \%$ \\
\hline
\end{tabular}

*Khi-négyzet próba: khi-négyzet $=51,837, d f=12, p=0,000$

Azoknak a tanulóknak, akiknek a neveltetése során nem került előtérbe a sport szeretete, fontossága, valamint ennek támogatása a szülők révén, az eredményeikben is tükröződik. 87,5\%-uk fejlesztésre szorul a NETFIT tesztbattériája szerint és ezek közül a tanulók közül egy tanuló sem tartozik az egészséges zónába. Azonban, ahol rendkívül fontosnak tartották a szülők a sport szeretetének elmélyítését ott a tanulók 64,7\%-a esett az egészséges zónába és csupán 9,8\%-a szorul fejlesztésre. 


\section{Konklúziók}

A mindennapos testnevelés növelte az iskolás gyerekek testmozgásra fordított idejét. A NETFITT adatok egyértelmüen azt bizonyítják, hogy a tanulók aerob fittségi állapotát (állóképesség) kell fejleszteni a testnevelés órákon és a sportfoglalkozásokon is. A testnevelés óra és az edzések hatékonyságának növelése érdekében a terhelés intenzitását kell növelni, hiszen a WHO (2015) fizikai aktivitás ajánlásában megjelenik, hogy az 5-17 éves korosztálynak legalább napi 60 perc mérsékelt és magas intenzitású fizikai aktivitást kellene végezni. Az órákon ez az ún. intenzitás mérés azonban még nem valósult meg, mellyel a tanulók fittségi szintje is javítható lenne. Az órai terhelés intenzitás mérésének kiváló eszköze lehet a pulzusmérés alkalmazása, melyet korábbi kutatásainkban vizsgáltunk, mint a NETFITet kiegészítő eszközt (Nagy és Müller 2017a, b, Nagy et. al. 201a, 2017b), mely a teljesítmény mérés minőségében (Czeglédi 2011, 2018) elengedhetetlen.

A testzsír\% csökkentése és az optimális BMI index kialakítása fontos a fiatal korosztályban, hiszen az elhízottak aránya még mindig magas. A gyermekeket érintő elhízás és túlsúly csökkentését tehát még a mindennapos testnevelés bevezetésével nem sikerült elérni, ám a tendencia megállításában sikeresnek bizonyult. 2010-ben Martos arról számolt be, hogy a 7 évesek körében minden negyedik lány és minden 5. fiú obesitasban szenved. Ez az arány megmaradt (Csányi et. al. 2015; Csányi és Kaj, 2017) napjainkra is.

Az elhízás mérséklésében csupán komplex népegészségügyi programok lehetnek sikeresek, mint amiröl a svédek is beszámoltak, ahol a fizikai aktivitás növelése és a táplálkozás megreformálása együttesen eredményezte a gyerekkori elhízás arányának csökkentését (Madarász és et.al., 2016). Az elhízás elleni komplex küzdelemben a családi háttérvizsgálatok szerepére és fontosságára több külföldi szerző is felhívja a figyelmet (Sundblom et al., 2008; Sundblom et al., 2010), akik elemezték a szociodemográfiai és szocioökonómiai háttér és az elhízás kapcsolatát is. Megállapították, hogy a négy és tíz éves korosztályban a kedvezőtlen szocioökonómiai helyzetü gyerekek elhízása magasabb gyakoriságú volt, mint a kedvezőbb szocioökonómiai státusszal rendelkezőké. Hazánkban (Bodzsár és Zsákai, 2016, Bodzsár et. al., 2015) ugyanezt tudták alátámasztani hazai nagymintás kutatásaikban.

A vizsgálat a szocioökonómiai háttér korrelációját volt hivatott bemutatni a NETFIT eredményekkel. Láthatjuk, hogy az eredmények kiértékelésénél figyelembe kell venni ezeket a komponenseket is, hiszen a konklúzió során ezzel kaphatunk egy széleskörü, átfogó képet.

A motivációs értékek egyik alappillére a családi szintér, amely meghatározza a serdülőkori mozgásos aktivitást, ahol az apa szerepe a meghatározó a sporttevékenység választásában valamint, annak gyakoriságában. Az információs és kommunikációs technológiáknak kiemelt jelentőségük van az információhoz való hozzáférésben (Ráthonyi et al., 2017), így javasoljuk a NETFIT mérés digitalizálását már a mérés során is valamint, egy háttérkérdőív mellékletet, amely segítségével egyénre szabottan tud a testnevelő tanár tájékozódni.

Az ifjúság fittségi mutatóinak és fizikai aktivitásának, szabadidős sportolásának növelése érdekében a lakóhely környéki rekreációs potenciálok (Michalkó és Lőrinc 2007, Bendíková, 2014, Dobay 2014, Pfau 2016, Lenténé et. al., 2018, Boda, 2018) feltérképezése, és ennek felhasználása, a sportszolgáltatások kínálatának elemzése (Ráthonyi-Odor et.al., 2016, Bácsné et. al., 2018) kiemelten fontos, mely hozzá járulhat a fiatalok, a felnőtt lakosság (Bácsné et. al., 2017, Biró et. al., 2018), és a fogyatékkal élök (Hidvégi et. al., 2018) életminőségének javításához egyaránt (Dinyáné és Pusztai, 2016).

A publikáció elkészitését az EFOP-3.6.2-16-2017-00003 számú projekt támogatta. A projekt az Európai Unió támogatásával, az Európai Szociális Alap társfinanszírozásával valósult meg. 


\section{IRODALOM}

Apor P. (2009). Fizikai edzés a cukorbetegség megelőzésében és kezelésében. Orvosi Hetilap. 150(13), 579-87.

Apor P. (2011). A cardiovascularis kockázat kapcsolata a fizikai aktivitással és a fittséggel. Orvos Hetilap, 152, 107-113.

Bácsné Bába É., Fenyves V., Dajnoki K. \& Szabados Gy (2018). Sportszolgáltatások kínálatának elemzése szervezeti szempontok alapján.International Journal of Engineering And Management Sciences / Müszaki És Menedzsment Tudományi Közlemények. 3:(4). 465-474.

Bácsné, Bába É.; Szabados, Gy. N.; Madarász, T. (2017).Munkavállalók fizikai állapot felmérésének tapasztalatai a $\mathrm{kkv}$ szektorban. Taylor: Gazdálkodás- És Szervezéstudományi Folyóirat: A Virtuális Intézet Közép-Európa Kutatására Közleményei IX. : 2 (28) . 179-187.

Bendíková, E. (2014): Lifestyle, physical and sport seducation and health benefit sofphysical activity. European researcher: international multidisciplinary journal. Sochi: Academic publishing house Researcher, 69(2-2): 343-348.

Biró M., Hidvégi P.; Tatár A., Pucsok M. J.,\& Lenténé P. A. (2018). Possibilities for improving the quality of life in Hungary in the northern great plain region. In: Šimonek J., Dobay B. (szerk.). Sport science in motion: proceedings from the scientific conference. Športová veda v pohybe: recenzovaný zborník vedeckých a odborných prác z konferencie. Komárno, Szlovákia : Univerzita J. Selyeho, 227-235.

Bocsi V. (2014): A sport szerepe a hallgatói életmódban. In Láczay M. (szerk): Társadalmi dimenziók az oktatásban. Debrecen, Debreceni Egyetemi Kiadó,pp. 273-292.

Boda E. (2018). Adventure park visiting habits among extreme athletes. In: Jaromír, Šimonek; Beáta, Dobay (szerk.) Sport science in motion: proceedings from the scientific conference. Športová veda v pohybe: recenzovaný zborník vedeckých a odborných prác z konferencie Komárno, Szlovákia : Univerzita J. Selyeho, 260-268

Bodolai M., Lívják E., Boda E., \& Bíró M. (2016). A jóga hatása a szervezetre, szerepe a stresszkezelésben. Acta Academiae Paedagogicae Agriensis Nova Series: Sectio Sport 43. 51-67.

Czeglédi L (2011).Minőségmenedzsment. EKF Eger.

Czeglédi L. (2018). Digital collections in physical education (PE). In: Jaromír, Simonek; Beáta, Dobay (szerk.) Sport science in motion: proceedings from the scientific conference. Športová veda v pohybe: recenzovaný zborník vedeckých a odborných prác z konferencie.Komárno, Szlovákia : Univerzita J. Selyeho, 244-251.

Charlton, R., Gravenor, M. B., Rees, A., Knox, G., Hill, R., Rahman, M. A. \& Brophy, S. (2014). Factors associated with low fitness in adolescents - A mixed methods study. BMC Public Health, 14(1).

Cleland, V. J., Ball, K., Magnussen, C., Dwyer, T., \& Venn, A. (2009). Socioeconomic position and the tracking of physical activity and cardiorespiratory fitness from childhood to adulthood. American Journal of Epidemiology, 170(9), 1069-1077.

Csányi T. \& Kaj M. (2017). A 2015/2016. tanév országos fittségmérési eredményei a Nemzeti Egységes Tanulói Fittségi Teszt (NETFIT®) alapján. Egészségfejlesztés 58:(4) 32-33.

Csányi T., Finn J. K., Welk J.G, Zhu W, Karsai I, Ihász F, Vass Z, Molnár L. (2015). Overview of the Hungarian National Youth Fitness Study. Res Q Exerc Sport. 86(sup1), S3-S12.

Dinyáné Szabó M., Pusztai G. (2016). Use of the short (5-item) version of the WHO wellbeing questionnaire in first year students of Semmelweis University: Az Egészségügyi 
Világszervezet öttételes jól-lét kérdőívének vizsgálata a Semmelweis Egyetem elsőéves hallgatóinak körében.Orvosi Hetilap 157 : (44) 1762-1768.

Dobay B.(2014). A Selye János Egyetem óvópedagógus hallgatói körében végzett felmérés a testmozgás tükrében. „Oktatás és tudomány a XXI. század elején”. Nemzetközi Tudományos Konferencia tanulmánykötete. 69-71.

Fintor G. (2016). A mindennapos testnevelés implementációja észak-alföldi általános iskolákban. Acta Academiae Paedagogicae Agriensis Nova Series: Sectio Sport 43:(1) 179-198.

Friedenreich C. M. (2001). Physical activity and cancer prevention: from observational to intervention research. Cancer Epidemiol Biomarkers Prev. 10(4), 287-301.

Golle, K., Granacher, U., Hoffmann, M., Wick, D., \& Muehlbauer, T. (2014). Effect of living area and sports club participation on physical fitness in children: a 4 year longitudinal study. BMC Public Health, 14(1), 49

Hamar P. (2012): „MindenNATos” testnevelés. Új Pedagógiai Szemle, 62(11-12), 87-97.

Hamar P. (2013). Balléri szellemiség - testkultúrába ágyazva. Új Pedagógiai Szemle 63:(7-8), 93-98.

Helmrich SP, Ragland DR, Leung RW, et al. (1991). Physical activity and reduced occurrence of non-insulin-dependent diabetes mellitus. N Engl J Med. 325(3), 147-52.

Herpainé Lakó J., Simon I. Á., Nábrádi Zs., Müller A. (2017). Képzés és Gyakorlat 15. évf. 4.

Herpainé Lakó J. (2018):Three generation research concerning sport and value. In: Jaromír, Šimonek; Beáta, Dobay (szerk.) Sport science in motion : proceedings from the scientific conference. Sportová veda v pohybe: recenzovaný zborník vedeckých a odborných prác z konferencie. Komárno, Szlovákia : Univerzita J. Selyeho, 274-280

Hidvégi P., Bíró M., Lenténé P. A., Tatár A., Pucsok J. M. (2018). The role of physical activity among people with disabilities. Šimonek J., Dobay B. (szerk.): Sport science in motion : proceedings from the scientific conference. Športová veda v pohybe: recenzovaný zborník vedeckých a odborných prác z konferencie. Komárno, Szlovákia : Univerzita J. Selyeho, 281-285

Iski, G. \& Rurik, I. (2014). The Estimated Economic Burden of Overweight and Obesityin Hungary [Becslések a túlsúly és az elhízás hazai gazdasági terheiről]. Orvosi Hetilap. 155 (35), 1406-1412.

Juhász I., Boda E., Bíró M., Müller A., Macra-Oşorhean M. D. (2016). Impact of teaching handball on the improvement of target accuracy of students in onsideration for the impac tassessment of the project "Handballatschool" Studia Universitatis Babes-Bolyai Educatio Artis Gymnasticae 61:(4), 15-27.

Jiménez-Pavón, D., Ortega, F. B., Ruiz, J. R., Chillón, P., Castillo, R., Artero, E. G. \& Noriega, M. J. (2010). Influence of socioeconomic factors on fitness and fatness in Spanish adolescents: the Avena Study. International Journal of Pediatric Obesity, 5(6), 467-473.

Juhász I., Boda E., Bíró M., Müller A. (2017). Célzásbiztonsági vizsgálatok a „Kézilabda az iskolában" programban résztvevő tanulók körében. Testnevelés, Sport, Tudomány / Physical Education, Sport, Science 2:(1-2), 44-48.

Lee, I. M. (2010). Physicalactivity and cardiacprotection. Curr. Sports Med. Rep., 9, 214219.

Lenténé P. A., Hidvégi P., Tatár A., Pucsok M. J., Biró M. (2018). Recreational potential of the northern great plain region in Hungary. Jaromír, Šimonek; Beáta, Dobay (szerk.) Sport science in motion : proceedings from the scientific conference. Športová veda $v$ pohybe: recenzovaný zborník vedeckých a odborných prác z konferencie..Komárno, Szlovákia : Univerzita J. Selyeho, 218-226. 
Madarász T., Bácsné Bába É. (2016). Survev ont he Employees’ Fitness Condition and the Employers' Health Preservation Possibilities in Case of Small and Medium-sized Enterprises. SEA: PracticaL Application Of Science IV: 2 (11), 205-212.,

Martos É. (2010). "Folyamatosan nö az elhízott gyerekek száma." Országos Élelmezés- és Táplálkozástudományi Intézet (OÉTI) Hyperlink

[http://www.webbeteg.hu/cikkek/elhizas/10859/folyamatosan-no-az-elhizott-gyerekekszama] Retrieved: 30 May 2016.

Michalkó G., Lőrincz K. (2007) A turizmus és az életminőség kapcsolatának nagyvárosi vetületei Magyarországon. Földrajzi Közlemények. 3.157-169.

Meszlényi E, Urbinné Borbély Sz, Seregi E, Morvay-Sey K, Rétsági E (2017). A mindennapos testnevelés néhány kérdésének vizsgálata. Sport-és Egészségtudományi Füzetek 1:(1), 8-18.

Mező, K. (2018). A kora gyermekkori családi nevelés hatása az érzelmi intelligencia kialakulására és fejlődésére. In: Vargáné, Nagy Anikó (szerk.) Családi nevelés. Debrecen, Magyarország: Didakt Kft.,43-59.

Moravecz M., Rábai D., Kovács K., Bácsné Bába É., \& Lenténé Puskás A. (2018). A sportolási szokások intézményi háttere hazai és határon túli kisebbségi magyar egyetemeken/föiskolákon.Magyar Sporttudományi Szemle 19, (75). 66-67.

Müller A. (2017). Role of the outdoor sports in the hungarian every-day P.E, recreation and tourism. Slovak Journal Of Sport Science $2: 2$

Müller A. (2018). Obesity and overweight in Hungary, focussing on among high school students. In: Bendíková E. (szerk.) Physical Activity, Health and Prevention III. International Scientific Conference: Conference Textbook Zilina, Szlovákia, IPV Institute of Education, IPV Inštitút priemyselnej výchovy, 6-16.

Müller A., Juhász I., Boda E., Nagy Zs., Biró M. (2018). Role of the handball at school programme in everyday physical education. Hungarian Educational Research Journal $8:(2), 7-23$.

Pfau, C. (2016). Hallgatói szabadidősport szervezése és jellemzői a felsőoktatásban.Taylor: Gazdálkodás- És Szervezéstudományi Folyóirat: A Virtuális Intézet Közép-Európa Kutatására Közleményei 8 : 4. 5-16.

Pluhar Z., Keresztes N., Piko B. (2004). A rendszeres fizikai aktivitás és a pszichoszomatikus tünetek kapcsolata általános iskolások körében. Sportorvosi Szemle, 45, 285-300.

Ráthonyi G., Bácsné Bába É., Szilágyi R. (2017): Innovatív eszközök alkalmazása a Debreceni Egyetem sportszervező képzésben. Taylor Gazdálkodás- és Szervezéstudományi Folyóirat: A Virtuális Intézet Közép-Európa Kutatására Közleményei. 9(3-4): 173-181.

Ráthonyi-Odor K., Ráthonyi G., Borbély A. (2016). Sportolni jó - felelősen a sport népszerüsítéséért. ACTA - Agrártudományi Közlemények, Acta Agraria Debreceniensis, 67. 71-76.

Ross R, Dagnone D, Jones P. J. H, et al. (2000). Reduction in obesity and related comorbid conditions after diet-induced weight loss or exercise-induced weight loss in men-a randomized, controlled trial. Ann Intern Med. 133(2), 92-103.

Stampfer M.J., Hu F. B., Manson J.E., et al. (2000). Primary prevention of coronary heart disease in women through diet and lifestyle. N Engl J Med. 343(1), 16-22.

Szépné V. H., Balatoni I. (2017). A gimnazista fiatalok mindennapos testnevelés keretében végezhető sportolása háttérfeltételeinek vizsgálata. Magyar Sporttudományi Szemle 18:(72), 72.

Szépné V. H., Katona É., Páll D., Balatoni I. (2017). Infrastuctural Background Of The Everyday Physical Education. Hungarian High Schools. Apstract, (11.)3-4. 
Youssef M. K. (2014). The impact of obesityonwalking and physical performance. Egypt J Intern Med 26:(2) 40-44..

Vandendriessche, J. B., Vandorpe, B. F., Vaeyens, R., Malina, R. M., Lefevre, J., Lenoir, M., \& Philippaerts, R. M. (2012). Variation in sport participation, fitness and motor coordination with socioeconomic status among Flemish children. Pediatric Exercise Science, 24(1), 113-128.

Walsh N. P., Gleeson M., Shephard R.J., et al. (2011). Position statement part one: immune function and exercise. Exerc Immunol Rev. 17:6-63.

Welk, G. J., Saint-Maurice, P. F., \& Csányi, T. (2015). Health-related physical fitness in Hungarian youth: Age, sex, and regional profiles. Research Quarterly for Exercise and Sport, 86, S45-S57.

Internetes hivatkozások:

NAT 2012: nemzeti alaptanterv 110/2012. (VI. 4.) Korm. rendelet: https://net.jogtar.hu/jogszabaly?docid=a1200110.kor

WHO: Obesity and overweight. World Health Organization, 2016. URL: http://www.who.int/mediacentre/factsheets/fs311/en/. (Letöltés dátuma: 2018.10.05.) 